\title{
PENGARUH LITERASI KEUANGAN DAN LINGKUNGAN KAMPUS TERHADAP MANAJEMEN KEUANGAN PRIBADI MAHASISWA
}

\author{
Setya Stanto Albertus ${ }^{1}$, Ari Wahyu Leksono ${ }^{2(*)}$, Rendika Vhalery ${ }^{3}$ \\ Universitas Indraprasta PGRI Jakarta, Indonesia
}

Setyastantoalbertus@yahoo.co.id ${ }^{1}$, arilordw@gmail.com² ${ }^{2}$, rendikavhalery31@gmail.com ${ }^{3}$

Received: 15 Agustus 2020

Revised: 17 Agustus 2020

Accepted: 20 Agustus 2020

\begin{abstract}
Masa pandemik merupakan masa dimana banyaknya permasalahan terjadi di berbagai belahan dunia. Masalah ini menyebabkan berbagai permasalahan baru dibidang lainnya, seperti di bidang ekonomi. Kejadian yang tidak stabil ini membutuhkan tindak lanjut agar dapat dihambat. Dampak ini dapat diminimalisir oleh kemampuan yang dimiliki oleh setiap individu. Kemampuan ini seperti me-manajemen keuangan pribadi. Manajemen keuangan pribadi dipengaruhi oleh beberapa faktor seperti literasi keuangan dan lingkungan kampus. Untuk mengetahui apakah literasi keuangan berpengaruh terhadap manajemen keuangan pribadi mahasiswa, apakah lingkungan kampus berpengaruh terhadap manajemen keuangan pribadi mahasiswa, apakah literasi keuangan dan dan lingkungan kampus berpengaruh terhadap manajemen keuangan pribadi mahasiswa, maka peneliti melakukan penelitian asosiatif. Populasi pada penelitian ini adalah mahasiswa Universitas Indraprasta PGRI jakarta yang melibatkan 116 mahasiswa. Dengan menggunakan kuesioner, data didapatkan dan diolah dengan teknik analisa regresi linear berganda. Hasil penelitian menunjukkan bahwa; literasi keuangan berpengaruh terhadap manajemen keuangan pribadi mahasiswa, lingkungan kampus berpengaruh terhadap manajemen keuangan pribadi mahasiswa, literasi keuangan dan lingkungan kampus berpengaruh terhadap manajemen keuangan pribadi mahasiswa.
\end{abstract}

Keywords: Literasi Keuangan; Lingkungan Kampus; Keuangan; Manajemen Keuangan Pribadi

(*) Corresponding Author: ～Leksono, arilordw@gmail.com, 089509096287

How to Cite: Albertus, S. S., Leksono, A. W., \& Vhalery, R. (2020). Pengaruh Literasi Keuangan Dan Lingkungan Kampus Terhadap Manajemen Keuangan Pribadi Mahasiswa. Research and Development Journal of Education, 1(1), 33-39.

\section{INTRODUCTION}

Masa pandemik merupakan masa dimana banyaknya permasalahan terjadi di berbagai belahan dunia. Masalah ini menyebabkan berbagai permasalahan baru dibidang lainnya, seperti di bidang politik, di bidang sosial, bahkan di bidang ekonomi. Dampak pandemik paling banyak dirasakan oleh masyarakat yaitu di bidang ekonomi. Perekonomian menjadi tidak stabil dan menyebabkan masalah baru lainnya seperti tidak adanya investasi (karena dipakai untuk kebutuhan sehari-hari selama pandemik), tidak adanya tabungan (Vhalery et al., 2019), dan sebagainya. Oleh sebab itu, mengatur dan mengelola keuangan (manajemen keuangan) menjadi salah satu alternatif untuk menghindari masalah keuangan yang berlebihan (Chotimah \& Rohayati, 2015). Kemampuan ini berguna untuk membuat pilihan keuangan (Alfilail \& Vhalery, 2020), mambahas uang dan masalah keuangan (Yushita, 2017), merencanakan masa depan (Leksono \& Vhalery, 2019), dan menanggapi kompeten untuk peristiwa kehidupan yang 
mempengaruhi keputusan keuangan sehari-hari (Yushita, 2017), termasuk peristiwa di ekonomi secara umum. (Yushita, 2017; Leksono \& Narsih, 2020).

Manajemen keuangan pribadi merupakan proses pencapaian tujuan keuangan secara pribadi melalui landasan ilmu manajemen keuangan yang terstuktur (Herlindawati, 2017). Dasar pembentuk perilaku ini didapat melalui berbagai cara, salah satunya melalui pendidikan (Leksono \& Narsih, 2020). Oleh sebab itu, mahasiswa sebagai orang yang menempuh pendidikan seharusnya mampu dalam mengoptimalkan kemampuannya untuk mengelola uang. Untuk mengetahui apakah mahasiswa mampu atau tidak mengoptimalkan kemampuannya dalam mengelola uang, peneliti melakukan studi pendahuluan dengan cara mewawancarai 5 orang mahasiswa yang belajar di salah satu pts yang ada di Jakarta Timur. Hasil wawancara menunjukkan bahwa 4 dari 5 orang mahasiswa tidak mampu mengoptimalkan kemampuan manajemen keuangannya walaupun sudah mendapat mata kuliah manajemen keuangan dan sejenisnya.

Ketidakmampuan mengoptimalkan kemampuan manajemen keuangan dikalangan mahasiswa dikarenakan beberapa hal. Pertama, kurangnya pengetahuan keuangan (Mendari \& Kewal, 2013). Kedua, mindset mereka (mahasiswa) yang terpaku pada satu hal (Sina, 2013). Ketiga, kondisi psikologis mahasiswa (Sina \& Noya, 2012). Keempat, tidak mampu bertanggung jawab atas apa yang telah dilakukan terhadap uang tersebut (Alfilail \& Vhalery, 2020). Alasan inilah yang menyebabkan mahasiswa menjadi lemah finansial. Akibatnya, banyak dari mereka tidak mampu mengatur keuangan.

Ada beberapa faktor yang mempengaruhi lemahnya kemampuan seseorang dalam memanajemen keuangannya. Faktor tersebut adalah literasi keuangan (Pradiningtyas \& Lukiastuti, 2019). Laily (2013) mengemukakan bahwa literasi keuangan berpengaruh terhadap perilaku mahasiswa dalam mengelola keuangan pribadi. Yushita (2017) menambahkan bahwa literasi keuangan merupakan kebutuhan dasar bagi setiap orang agar terhindar dari masalah keuangan. Oleh sebab itu, literasi keuangan mempunyai peranan penting dalam mengatur atau mengendalikan keuangan seseorang. Di lain pihak, Susdiani (2017) menjelaskan bahwa literasi tidak berpengaruh terhadap manajemen investasi keuangan dikarenakan rendahnya literasi orang tersebut. Perbedaan pendapat dari beberapa ahli ini menjadi acuan peneliti untuk meneliti literasi keuangan lebih lanjut dengan tujuan untuk mengetahui apakah literasi keuangan berpengaruh atau tidak berpengaruh terhadap manajemen keuangan pribadi.

Faktor lain yang mempengaruhi lemahnya kemampuan manajemen keuangan pribadi mahasiswa yaitu lingkungan kampus. Menurut Vhalery et al. (2019) lingkungan sosial seperti lingkungan kampus dapat mempengaruhi pengelolaan keuangan mahasiswa. Menurut Vhalery (2019) kondisi lingkungan kampus mampu meningkatkan konsentrasi individu terhadap sesuatu. Bahkan, dilingkungan ini seseorang juga dapat mengembangkan kemampuannya berdasarkan pengamatan yang dia lakukan terhadap temannya (Pradiningtyas \& Lukiastuti, 2019). Oleh karena itu, lingkungan kampus dapat menjadi salah satu faktor yang dapat mempengaruhi manajemen keuangan seseorang. Namun, hasil penelitian yang dilakukan Vhalery (2020) mengemukakan hal yang berlawanan, bahwa lingkungan kampus tidak berpengaruh terhadap pengelolaan keuangan pribadi mahasiswa. Perbedaan pendapat dari beberapa ahli ini menjadi acuan peneliti untuk meneliti lingkungan kampus lebih lanjut dengan tujuan untuk mengetahui apakah lingkungan kampus berpengaruh atau tidak berpengaruh terhadap manajemen keuangan pribadi.

Berdasarkan uraian singkat dari yang telah disampaikan, maka peneliti tertarik untuk meneliti tentang "pengaruh literasi keuangan dan lingkungan kampus terhadap manajemen keuangan pribadi mahasiswa". 


\section{METHODS}

Penelitian ini merupakan penelitian asosiatif yang merupakan penelitian kuantitatif. Penelitian asosiatif digunakan untuk mengetahui pengaruh variabel independen terhadap variabel dependen. Populasi penelitian adalah mahasiswa Universitas Indraprasta PGRI yang berstatus aktif. Teknik pengambilan sampel menggunakan accidental sampling yang berjumlah 116 orang. Teknik pengumpulan data yang digunakan adalah kuesioner. Kuesioner yang dibagikan kepada responden berisi data tentang variabel literasi keuangan, lingkungan kampus dan manajemen keuangan. Teknik analisis data yang digunakan adalah analisis data statistik dengan menggunakan regresi linear berganda.

\section{RESULTS \& DISCUSSION}

\section{Results}

Setelah data didapatkan maka dilanjutkan dengan pengujian statistik. Berdasarkan perhitungan statistik didapat nilai koefisien regresi linear berganda sebagai berikut :

Tabel 1.

Koefisien Regresi Linear Berganda

\begin{tabular}{|c|c|c|c|c|c|c|}
\hline \multicolumn{7}{|c|}{ Koefisien Regresi Linear Berganda } \\
\hline \multirow[b]{2}{*}{ Model } & & \multicolumn{2}{|c|}{$\begin{array}{l}\text { Unstandardized } \\
\text { Coefficients }\end{array}$} & \multirow{2}{*}{$\begin{array}{c}\text { Standardized } \\
\text { Coefficients } \\
\text { Beta } \\
\end{array}$} & \multirow[b]{2}{*}{$\mathbf{t}$} & \multirow[b]{2}{*}{ Sig. } \\
\hline & & B & Std. Error & & & \\
\hline \multirow[t]{3}{*}{1} & (Constant) & 7.527 & 3.157 & & 2.384 & .019 \\
\hline & $\mathrm{X} 1$ & 1.043 & .104 & .720 & 10.053 & .000 \\
\hline & $\mathrm{X} 2$ & .150 & .065 & .165 & 2.301 & .023 \\
\hline
\end{tabular}

Sumber : Data Olahan Primer (2020)

Dari tabel 1 diketahui bahwa nilai $\mathrm{Y}=7.527+1.043 \mathrm{X}_{1}+0.0150 \mathrm{X}_{2}$. Dan berdasarkan tabel 1 juga dapat diketahui bahwa nilai $t_{\text {hitung }}$ untuk variabel $\mathrm{X}_{1}$ (literasi keuangan) sebesar 10.053 dengan nilai sig. Sebesar 0.000 dan nilai variabel $\mathrm{X}_{2}$ (lingkungan kampus) sebesar 2.301 dengan nilai sig. Sebesar 0.023. Berdasarkan ketentuan pengambilan keputusan bahwa, apabila nilai $t_{\text {hitung }}>t_{\text {tabel }}$ maka ada pengaruh variabel independen terhadap variabel independen. Sebaliknya, apabila nilai $t_{\text {hitung }}<\mathrm{t}_{\text {tabel }}$ maka tidak ada pengaruh variabel independen terhadap variabel independen. Nilai $t_{\text {tabel }}$ untuk taraf kesalahan 5\% (0.05) dan derajat kebebasan (df) $=\mathrm{n}-\mathrm{k}=116-3=113$, maka didapat nilai $\mathrm{t}_{\text {tabel }}$ sebesar 1.981 .

Berdasarkan ketentuan tersebut dapat disimpukan bahwa adanya adanya pengaruh literasi keuangan terhadap manajemen keuangan pribadi mahasiswa secara signifikan. Kesimpulan ini ditentukan berdasarkan nilai $t_{\text {hitung }}>t_{\text {tabel }}$ yaitu 10.053 $>1.981$ dengan nilai signifikan sebesar $0.000<0.050$. Berdasarkan ketentuan tersebut juga dapat disimpukan bahwa adanya adanya pengaruh lingkungan kampus terhadap manajemen keuangan pribadi mahasiswa secara signifikan. Kesimpulan ini ditentukan berdasarkan nilai $t_{\text {hitung }}>t_{\text {tabel }}$ yaitu $2.301>1.981$ dengan nilai signifikan sebesar $0.023<0.050$.

Selain membandingkan nilai $t_{\text {hitung }}$ dengan $t_{\text {tabel }}$, peneliti juga membandingkan nilai $\mathrm{f}_{\text {hitung }}$ dengan nilai $\mathrm{f}_{\text {tabel }}$. Membandingkan nilai $\mathrm{f}_{\text {hitung }}$ dengan nilai $\mathrm{f}_{\text {tabel }}$ bertujuan untuk mengetahui apakah variabel $\mathrm{X}_{1}$ dan $\mathrm{X}_{2}$ mempunyai pengaruh terhadap $\mathrm{Y}$ dengan 
ketentuan; apabila nilai $\mathrm{F}_{\text {hitung }}>\mathrm{F}_{\text {tabel }}$ maka ada pengaruh variabel $\mathrm{X}_{1}$ dan $\mathrm{X}_{2}$ terhadap variabel $Y$. Sebaliknya, apabila nilai $F_{\text {hitung }}<F_{\text {tabel }}$ maka tidak ada pengaruh variabel $X_{1}$ dan $\mathrm{X}_{2}$ terhadap variabel $\mathrm{Y}$. Berdasarkan perhitungan untuk mencari nilai $\mathrm{F}_{\text {tabel }}$ maka didapat nilai $\mathrm{F}_{\text {tabel }}$ sebesar 2.683. Untuk mengetahui hasil $\mathrm{F}_{\text {hitung }}$ dapat diketahui dari tabel berikut ini.

Tabel 2.

Anova Regresi Linear Berganda

\begin{tabular}{|c|c|c|c|c|c|c|}
\hline Model & & $\begin{array}{l}\text { Sum of } \\
\text { Squares } \\
\end{array}$ & df & Mean Square & $\mathbf{F}$ & Sig. \\
\hline \multirow[t]{3}{*}{1} & Regression & 6802.129 & 2 & 3401.065 & 140.826 & .000 \\
\hline & Residual & 2729.043 & 113 & 24.151 & & \\
\hline & Total & 9531.172 & 115 & & & \\
\hline
\end{tabular}

Sumber : Data Olahan Primer (2020)

Dari tabel 2 diketahui bahwa nilai $\mathrm{F}_{\text {hitung }}$ sebesar 140.826 dengan nilai signifikan sebesar 0.000. Berdasarkan ketentuan tersebut dapat disimpukan bahwa adanya adanya pengaruh literasi keuangan dan lingkungan kampus terhadap manajemen keuangan pribadi mahasiswa secara signifikan. Kesimpulan ini ditentukan berdasarkan nilai $F_{\text {hitung }}>F_{\text {tabel }}$ yaitu $140.826>2.683$ dengan nilai signifikan sebesar $0.000<0.050$. selanjutnya mengetahui berapa besar peran literasi keuangan dan lingkungan kampus terhadap manajemen keuangan pribadi. Hal ini dapat diketahui dari tabel berikut ini.

Tabel 3.

Model Summary

\begin{tabular}{lc|c|c|c}
\hline Model & R & R Square & $\begin{array}{c}\text { Adjusted R } \\
\text { Square }\end{array}$ & $\begin{array}{c}\text { Std. Error of the } \\
\text { Estimate }\end{array}$ \\
\hline 1 & .845 & .714 & .709 & 4.914 \\
\hline
\end{tabular}

Sumber : Data Olahan Primer (2020)

Dari tabel 3 diketahui bahwa nilai adjusted $\mathrm{R}$ square sebesar 0.709 atau sebesar 70,9\%. Artinya, peran literasi keuangan dan lingkungan kampus terhadap manajemen keuangan pribadi sebesar 70,9\% yang berada pada kategori tinggi. Sedangkan 29,1\% lainnya disumbang oleh variabel lain yang tidak diteliti dalam penelitian ini.

\section{Discussion}

1. Literasi keuangan terhadap manajemen keuangan pribadi mahasiswa

Hasil analisa data menunjukkan bahwa adanya pengaruh literasi keuangan terhadap manajemen keuangan pribadi mahasiswa secara signifikan. Hasil penelitian ini sejalan dengan penelitian yang dilakukan oleh Chotimah \& Rohayati (2015) yang mengungkapkan bahwa literasi keuangan berpengaruh terhadap manajemen keuangan pribadi. Hasil ini juga diperkuat oleh hasil penelitian yang dilakukan oleh Vhalery et al. (2019) yang menyatakan bahwa literasi keuangan berpengaruh terhadap pengelolaan keuangan.

Menurut Muttaqiin et al. (2018) manajemen keuangan yang terbentuk dari literasi keuangan memberikan ilmu mengenai bagaimana cara untuk meningkatkan kesejahteraan finansial melalui peningkatan keuangan untuk meminimalisir dampak 
keuangan yang berlebihan. Selain itu, literasi keuangan dapat meningkatkan pengetahuan tentang konsep keuangan, kemampuan untuk berkomunikasi tentang keuangan, kemampuan untuk mengelola keuangan pribadi, kemampuan dalam membuat keputusan keuangan, dan keyakinan untuk membuat perencanaan keuangan masa depan (Remund, 2010; Margaretha \& Pambudhi, 2015). Jadi, literasi keuangan sangat penting untuk manajemen keuangan pribadi.

2. Lingkungan kampus terhadap manajemen keuangan pribadi mahasiswa

Hasil analisa data menunjukkan bahwa adanya pengaruh lingkungan kampus terhadap manajemen keuangan pribadi mahasiswa secara signifikan. Hasil penelitian ini berlawanan dengan hasil yang diteliti oleh Vhalery (2020) yang menjelaskan bahwa lingkungan kampus tidak berpengaruh terhadap pengelolaan keuangan. Perbedaan hasil ini dikarenakan beberapa faktor seperti jumlah sampel, waktu pelaksanaan saat penelitian, instrumen penelitian, dan lainnya. Hasil penelitian ini juga bertolak belakang dengan hasil penelitian yang dilakukan oleh Sobaya et al. (2014) yang mengungkapkan bahwa lingkungan sosial (lingkungan kampus) tidak berpengaruh terhadap pengelolaan keuangan. Perbedaan ini disebabkan oleh beberapa hal seperti tempat penelitian, waktu penelitian, populasi penelitian, sampel penelitian, teknik pengumpulan data, teknik analisis data, dan lainnya.

3. Literasi keuangan dan lingkungan kampus terhadap manajemen keuangan pribadi mahasiswa

Hasil analisa data menunjukkan bahwa adanya pengaruh literasi keuangan dan lingkungan kampus terhadap manajemen keuangan pribadi mahasiswa secara signifikan. Hasil penelitian ini sejalan dengan hasil penelitian yang dilakukan oleh Sobaya et al. (2014) yang menjelaskan bahwa literasi keuangan dan lingkungan sosial (salah satunya lingkungan kampus) berpengaruh terhadap manajemen keuangan. Dalam melakukan manajemen keuangan diperlukan perencanaan keuangan untuk mencapai tujuan, baik tujuan jangka pendek maupun jangka panjang (Parmitasari et al., 2018). Namun, apabila mereka memiliki literasi keuangan yang rendah, maka dapat memperbesar kemungkinan individu melakukan kesalahan dalam merencanakan keuangannya dan pada akhirnya berdampak pada penurunan kesejahteraannya (Mendari \& Soejono, 2019). Dan apabila hal ini terjadi maka lingkungan sosial lah yang dapat menghambat hal tersebut (Sobaya et al., 2014). Tujuan Manajemen keuangan adalah untuk mencapai efisiensi dan efektivitas keuangan seperti memaksimalkan pemasukan dan pengeluaran uang (Widiawati, 2020).

\section{CONCLUSION}

Hasil analisa data mengungkapkan bahwa literasi keuangan berpengaruh terhadap manajemen keuangan pribadi, lingkungan kampus berpengaruh terhadap manajemen keuangan pribadi, literasi keuangan dan lingkungan kampus berpengaruh terhadap manajemen keuangan pribadi. Literasi keuangan dan lingkungan kampus mempunyai peran sebesar $70,9 \%$ terhadap manajemen keuangan pribadi. Sedangkan 29,1\% disumbang oleh variabel lain yang tidak diteliti dalam penelitian ini.

Hasil penelitian ini diharapkan mampu memberikan implikasi pada peneliti berikutnya, tempat yang menjadi objek penelitian, dan sebagainya. Untuk penelitian selanjutnya diharapkan menggunakan variabel lainnya yang tidak diteliti dalam penelitian ini. Apabila menggunakan variabel yang sama, diharapkan menggunakan indikator, populasi, sampel, atau data penelitian yang lainnya. 


\section{REFERENCES}

Alfilail, S. N., \& Vhalery, R. (2020). PENGARUH SELF-ESTEEM DAN SELFAWARENESS TERHADAP PENGELOLAAN UANG SAKU. Research and Development Journal of Education, 6(2), 38-48.

Amanita Novi Yushita. (2017). Pentingnya Literasi Keuangan Bagi Pengelolaan Keuangan Pribadi. Jurnal Nominal, VI(1), 15.

Chotimah, C., \& Rohayati, S. (2015). Pengaruh Pendidikan Keuangan Di Keluarga, Sosial Ekonomi Orang Tua, Pengetahuan Keuangan, Kecerdasan Spiritual, Dan Teman Sebaya Terhadap Manajemen Keuangan Pribadi Mahasiswa S1 Pendidikan Akuntansi Fakultas Ekonomi Universitas Negeri Surabaya.

Herlindawati, D. (2017). Pengaruh Kontrol Diri, Jenis Kelamin, Dan Pendapatan Terhadap Pengelolaan Keuangan Pribadi Mahasiswa Pascasarjana Universitas Negeri Surabaya. Jurnal Ekonomi Pendidikan Dan Kewirausahaan, 3(2), 158.

Laily, N. (2013). Pengaruh Literasi Keuangan Terhadap Perilaku Mahasiswa Dalam Mengelola Keuangan. Journal of Accounting and Business Education, 1(4). https://doi.org/http://dx.doi.org/10.26675/jabe.v1i4.6042

Leksono, A. W., \& Narsih, D. (2020). Peran Pendidikan Keuangan dan Pengaruhnya Terhadap Literasi Keuangan pada Siswa SMA PGRI 4 Jakarta. Jurnal Ilmiah Wahana Pendidikan, 6(2), 110-115. https://jurnal.unibrah.ac.id/index.php/JIWP

Leksono, A. W., \& Vhalery, R. (2019). Pengaruh Self-Knowledge Dan Self-Deception Terhadap Pengelolaan Uang Saku. Research and Development Journal of Education, 6(1), 28-40.

Margaretha, F., \& Pambudhi, R. A. (2015). Tingkat Literasi Keuangan Pada Mahasiswa S-1 Fakultas Ekonomi. JMK, 17(1), 76-85.

Mendari, A. S., \& Kewal, S. S. (2013). Tingkat Literasi Keuangan Di Kalangan Mahasiswa Stie Musi. Jurnal Economia, 9(2), 130-140.

Mendari, A. S., \& Soejono, F. (2019). Hubungan Tingkat Literasi dan Perencanaan Keuangan. Modus Journals, 31(2), 227-240.

Muttaqiin, N., Agustina, H., \& Khusnah, H. (2018). Perencanaan Keuangan Pribadi Untuk Remaja. 2(1).

Parmitasari, R. D. A., Alwi, Z., \& S., S. (2018). Pengaruh Kecerdasan Spritual dan Gaya Hidup Hedonisme terhadap Manajemen Keuangan Pribadi Mahasiswa Perguruan Tinggi Negeri di Kota Makassar. Jurnal Minds: Manajemen Ide Dan Inspirasi, 5(2), 147. https://doi.org/10.24252/minds.v5i2.5699

Pradiningtyas, T. E., \& Lukiastuti, F. (2019). Pengaruh Pengetahuan Keuangan dan Sikap Keuangan terhadap Locus of Control dan Perilaku Pengelolaan Keuangan Mahasiswa Ekonomi. Jurnal Minds: Manajemen Ide Dan Inspirasi, 6(1), 96-112. https://doi.org/10.24252/minds.v6i1.9274

Remund, D. L. (2010). Financial literacy explicated: The case for a clear definition in an increasingly complex economy. The Journal of Consumer Affairs, 44(2), 276-295

Sina, P. G. (2013). Pengaruh Cognitive Style Dan Global Mindset Terhadap Manajemen Keuangan Pribadi Terhadap Intensi Berwirausaha. Journal Manajemen Teori Dan Terapan, 6(1), 52-66.

Sina, P. G., \& Noya, A. (2012). Pengaruh Kecerdasaan Spirtual Terhadap Pengelolaan Keuangan Pribadi. Jurnal Manajemen, 11(2), 171-188.

Sobaya, S., Hidayanto, M. F., \& Safitri, J. (2014). Pengaruh Literasi Keuangan Dan Lingkungan Sosial Terhadap Perencanaan Keuangan Pegawai Universitas Islam Indonesia Yogyakarta. 1, 115-128.

Susdiani, L. (2017). Pengaruh Financial Literacy dan Financial Experience Terhadap Perilaku Perencanaan Investasi PNS Di Kota Padang. Jurnal Pembangunan 
Nagari, 2(1), 61-74.

Vhalery, R. (2019). Pengaruh Komitmen Belajar dan Lingkungan Kampus Terhadap Hasil Belajar Matematika Ekonomi. Lembaran Ilmu Kependidikan, 48(1), 18-22.

Vhalery, R. (2020). Pengaruh Lingkungan Kampus Dan Motivasi Keuangan Pada Pengelolaan Uang Saku Mahasiswa Universitas Indraprasta. Jurnal Inovasi Pendidikan Ekonomi (JIPE), 10(1), 64-70.

Vhalery, R., Leksono, A. W., \& Irvan, M. (2019). Pengaruh Literasi Keuangan, Usia, dan Bimbingan Orang Tua terhadap Pengelolaan Uang Saku Mahasiswa UNINDRA. Jurnal Pendidikan Ekonomi, 12(1), 10-17.

Widiawati, M. (2020). Pengaruh Literasi Keuangan, Locus of Control , Financial SelfEfficacy, Dan Love of Money Terhadap Manajemen Keuangan Pribadi. Prisma (Platform Riset Mahasiswa Akuntansi), 1(1), 97-108. https://ojs.stiesa.ac.id/index.php/prisma 